\title{
The effect of optic neuritis treatment trial (ONTT) combined corticosteroid regimen on pattern reversal visual evoked potentials: a prospective follow-up study
}

Padmini Dahanayake ${ }^{1,2^{*}}$, Tharaka L. Dassanayake ${ }^{1,2,3}$, Manoji Pathirage ${ }^{2,4}$, Saman Senanayake ${ }^{5}$, Mike Sedgwick ${ }^{1}$ and Vajira S. Weerasinghe $e^{1,2}$

\begin{abstract}
Background: The combined corticosteroid regimen of the original Optic Neuritis Treatment Trial (ONTT) is used in many centers to treat optic neuritis. Though pattern reversal visual evoked potentials (PRVEPs) are a sensitive, standard measure of visual conduction in optic neuritis, no studies hitherto have investigated the effect of combined ONTT regimen on PRVEPs. We aimed to determine the effect of combined corticosteroid regimen of the ONTT on changes of PRVEPs in patients with first-episode optic neuritis over 3 months post-treatment.

Methods: This is a prospective, observational study in which 44 patients with optic neuritis were seen pretreatment (baseline) and follow-up, at 1 month (FU1) and 3 months (FU2). Twenty-nine patients were treated with ONTT combined regimen (ONTT+ Group) while 15 were conservatively managed without corticosteroids (ONTTGroup). The median latency and amplitude values of the P100 PRVEP component and the visual acuity (i.e. LogMAR values) at pre-treatment, FU1 and FU2 were compared in the two groups using Friedman's rank test and Wilcoxon Signed Ranks test.

Results: Median P100 latency improved significantly (to the normal range) as early as by 1 month after the commencement of treatment in the ONTT+ Group, and then remained significantly lower than the baseline over next 2 months. In the ONTT-Group, the median P100 latency improved more slowly over the two follow up assessments and reached the normal range by 3 months. Median visual acuity values also improved significantly at 1 and 3 months after the commencement of treatment in the ONTT+ Group but not in the ONTT-Group.

Conclusion: ONTT combined corticosteroid regimen improves conduction in the visual pathways of patients with first-episode optic neuritis earlier than does conservative management. We provide electrodiagnostic evidence that combined ONTT regimen-compared with conservative management-results in early remission of visual conduction abnormalities in first-episode optic neuritis.
\end{abstract}

Keywords: Visual evoked potentials, P100, Prospective study, Optic neuritis, ONTT combined regimen, Corticosteroids, Visual conduction, Remyelination

\footnotetext{
* Correspondence: padminid@pdn.ac.lk

${ }^{1}$ Department of Physiology, Faculty of Medicine, University of Peradeniya,

Peradeniya 20400, Sri Lanka

${ }^{2}$ Teaching Hospital, Peradeniya 20400, Sri Lanka

Full list of author information is available at the end of the article
}

(c) The Author(s). 2021 Open Access This article is licensed under a Creative Commons Attribution 4.0 International License, which permits use, sharing, adaptation, distribution and reproduction in any medium or format, as long as you give appropriate credit to the original author(s) and the source, provide a link to the Creative Commons licence, and indicate if changes were made. The images or other third party material in this article are included in the article's Creative Commons licence, unless indicated otherwise in a credit line to the material. If material is not included in the article's Creative Commons licence and your intended use is not permitted by statutory regulation or exceeds the permitted use, you will need to obtain permission directly from the copyright holder. To view a copy of this licence, visit http://creativecommons.org/licenses/by/4.0/. The Creative Commons Public Domain Dedication waiver (http://creativecommons.org/publicdomain/zero/1.0/) applies to the data made available in this article, unless otherwise stated in a credit line to the data. 


\section{Background}

Optic neuritis is characterized by an inflammation and demyelination of the optic nerve [1], and is traditionally treated with corticosteroids. Pattern-reversal visual evoked potentials (PRVEPs) are a sensitive measure to assess conduction delay in the optic nerve pathway caused by demyelination [2]. The Optic Neuritis Treatment Trial (ONTT) conducted in a large sample of patients over a 15-year follow up starting from 1988, found a combination of intravenous and oral corticosteroids produced rapid recovery, a better short-term functional outcome and reduced recurrence of optic neuritis in multiple sclerosis [1]. Since then, combined corticosteroid regimen has become the standard treatment for optic neuritis. The outcome measures of the study were visual acuity, contrast sensitivity, colour vision and visual field testing. Although these are clinically important functional outcome measures, objective assessment of the conduction along the optic pathways using visual evoked potentials (VEPs) would add to the clinicians' understanding of the recovery of their patients [3, 4].

Given that VEPs were not used as an outcome measure in the original ONTT study, or to best of our knowledge, in any subsequent combined corticosteroid trials, we used pattern reversal VEPs (PRVEPs) to assess the short-term recovery of the visual conduction pathways in patients with optic neuritis who underwent the combined ONTT regimen. Specifically, we assessed the PRVEPs of two cohorts of patients with newly-diagnosed, first-episode optic neuritis who underwent 1) combined ONTT regimen or 2) conservative management with no corticosteroids at three time points: pre-treatment (baseline); and 1 month and 3 months following commencement of clinical management.

Previous studies have employed VEPs in assessment of recovery of optic neuritis following either oral or intravenous corticosteroid treatment [5-10], but none have assessed the effect of combined ONTT regimen on the recovery of VEPs. We also compared the baseline VEP measures of the whole group of patients with a reference group of healthy individuals.

\section{Methods}

\section{Study setting and design}

This was a prospective, observational study carried out from February 2017 to October 2019 at the Ophthalmology Centre of the National Hospital Kandy and the Clinical Neurophysiology Department of the Teaching Hospital Peradeniya, two tertiary care referral centres of Sri Lanka. The study design and protocols complied with the code of ethics of the World Medical Association Declaration of Helsinki [11]. Ethical clearance for the study was obtained from the Ethical Review Committee, Faculty of Medicine, University of Peradeniya, Sri Lanka.
The procedure was explained, and informed written consent was obtained from the participants recruited in the study.

\section{Characteristics of participants}

Forty-four patients $\geq 18$ years of age with the diagnosis of the first-episode optic neuritis within 3 weeks after onset of ocular symptoms were recruited. Participants were excluded if they had received corticosteroids in the previous 30 days, had other neurological illnesses, or other medical conditions that might affect visual outcomes such as, but not limited to, diabetic retinopathy, glaucoma, or cataracts. One of the co-authors (SS), who is a specialist ophthalmologist clinically examined and conducted fundoscopic examination of the potential participants. Patients were diagnosed based on sudden onset of visual impairment, positive relative afferent pupillary defect (RAPD), fundoscopic changes, and PRVEP changes (which we used as the baseline VEP measurements). None of the recruited participants had fundoscopic features of other eye pathologies that might confound our results.

To compare the baseline VEP measures of the above group with optic neuritis, we also recruited a reference group of 44 healthy participants of age $\geq 18$ years with normal or corrected-to-normal vision in neuroophthalmologic examination. They had no concomitant or previous eye diseases and no evidence of neurological diseases.

\section{Procedure}

All the participants (test and healthy reference groups) had a baseline neuro-ophthalmologic assessment which included measurements of visual acuity, visual field, colour vision, pupillary reflexes, fundoscopy and ocular motor examination.

The best corrected visual acuity was examined using a Snellen chart and converted into a logarithm of the Minimal Angle of Resolution (LogMAR) units for statistical analysis. We tested all participants with pattern electroretinography (PERG) to exclude possible macular pathology (as indexed by delayed P50 PERG component latency) that might delay VEPs despite the post-retinal pathways being intact, and thus 1) to exclude individuals with macular pathologies from the healthy reference group and 2) to prevent patients with isolated macular pathologies being recruited erroneously into the optic neuritis group [12]. We have reported the PERG assessment techniques in detail previously [13].

All participants underwent PRVEPs assessments at the Clinical Neurophysiology Department of the Teaching Hospital Peradeniya. A Natus EMG/NCV/EP machine (Natus Neurology Inc. USA) was used to produce visual stimuli, and to record and average the PRVEP 
waveforms. The recording technique conformed to the International Society for Clinical Electrophysiology of Vision (ISCEV) guidelines [14]. PRVEPs were recorded in response to $2 \mathrm{~Hz}$ pattern-reversal checkerboard stimuli presented on a cathode ray tube monitor with a black-and-white alternating checkerboard pattern. The field size subtended and visual angle $15^{\circ}$ at the shortest diagonal. The contrast between black and white squares was $\geq 80 \%$ as defined by Michelson contrast. Silver/silver chloride electrodes were used to record VEPs. An active electrode was fixed at the $\mathrm{Oz}$ position, reference electrode at $\mathrm{Fz}$ position and ground electrode at $\mathrm{Cz}$ position according to the $10 / 20$ electrode placement standards. The electrode impedances were maintained below $5 \mathrm{k} \Omega$. Mean photopic luminance was $50 \mathrm{cdm}^{-2}$. The mean luminance of the stimulus screen was constant during checkerboard reversals and varied less than $30 \%$ between the center and periphery of the visual field. Each eye was tested separately. A band-pass filter with low- and highcutoff frequencies of $1 \mathrm{~Hz}$ and $100 \mathrm{~Hz}$ was applied. One hundred sweeps were averaged online, and two averaged waveforms were recorded to check for reproducibility. The peak amplitudes and latencies of the N75, P100 and N145 components were measured.

\section{Treatment and follow up}

A baseline (pre-treatment) PRVEP measurement was done in all patients with optic neuritis and the reference group of healthy individuals.

The decision to treat with ONTT regimen or to manage conservatively was taken by the treating ophthalmologists on an individualized basis $[15,16]$. Of the 44 patients, 29 were treated with the full course of ONTT regimen (ONTT+ Group) which was 3 doses of IV methylprednisolone $(1 \mathrm{~g} /$ day $)$ followed by 11 days of oral prednisolone $(1 \mathrm{mg} / \mathrm{kg} /$ day $)$ with a 3 -day short oral tapering course $[1,16,17]$. The remaining 15 patients were not treated with ONTT combined regimen, and were managed conservatively (ONTT-Group) [18]. Each cohort was followed up with two subsequent assessments using PRVEP: after 1 month (FU1) and then after 3 months (FU2) after commencement of treatment (Fig. 1).

\section{Data analysis}

PRVEP latencies and amplitudes were the electrophysiological outcome measures. The primary PRVEP measure was the P100 latency of PRVEP because P100 latencies are a reliable measure of the functional integrity of the visual pathway. P100 latency was also found to correlate with visual acuity and recovery of visual fields in patients with optic neuritis $[5,19]$. In addition, visual acuity reported in LogMAR units were considered the main clinical outcome measure. These outcome measures showed skewed distributions; and therefore, are reported as medians and interquartile ranges (IQR), and were analysed using non-parametric tests. In four VEP assessments (of the patient group) the P100 VEP component was absent. In those cases, a dummy value of $999 \mathrm{~ms}$ was assigned for these entries to retain those cases in the samples and thus avert the group's statistics biasing towards better values. Given the number of such cases were a small fraction and comparisons are nonparametric, this approach did not affect the median and IQRs [5]. In

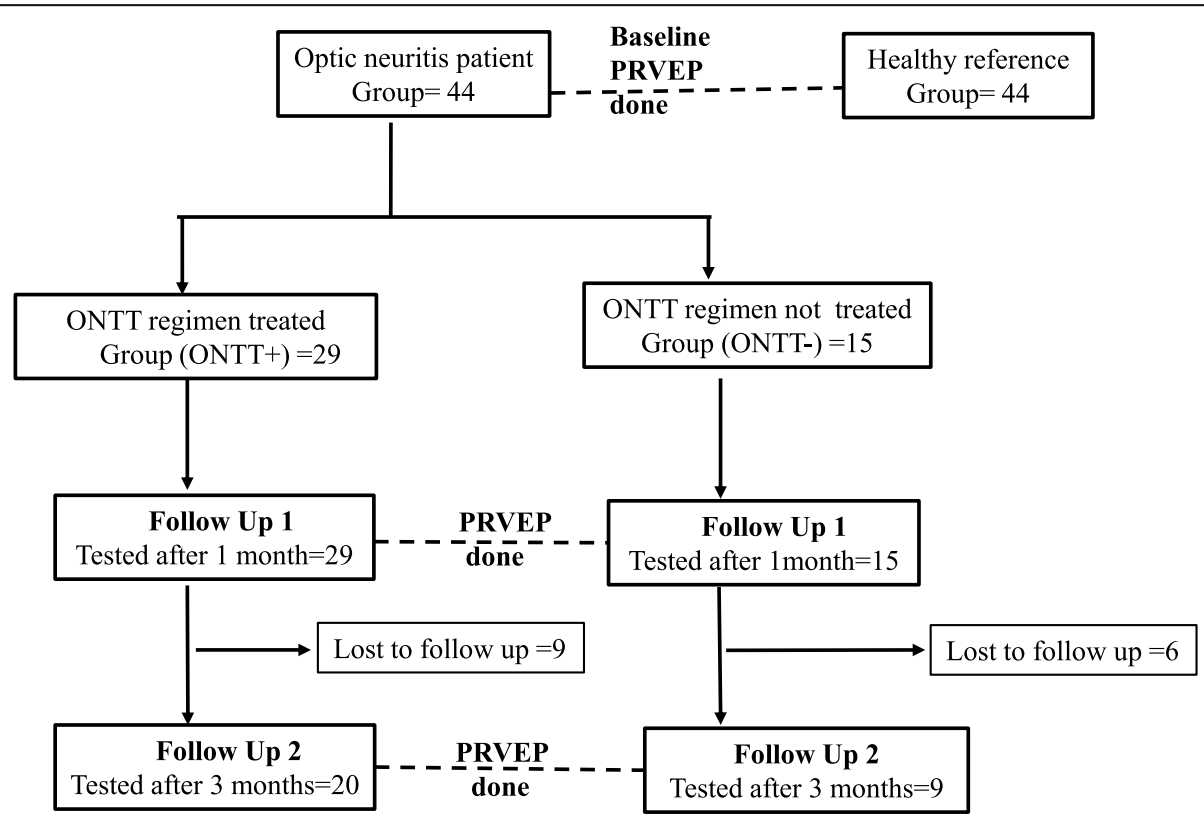

Fig. 1 Participants recruitment and follow up 
Table 1 Comparison of baseline PRVEP measures between optic neuritis patients and healthy individuals

\begin{tabular}{|c|c|c|c|}
\hline \multirow{2}{*}{$\begin{array}{l}\text { PRVEP } \\
\text { measure }\end{array}$} & \multicolumn{2}{|l|}{ Median (IQR) } & \multirow{2}{*}{$\begin{array}{l}P \text { value } \\
\text { (Mann-Whitney } U \text { test) }\end{array}$} \\
\hline & $\begin{array}{l}\text { Optic neuritis patient Group } \\
(n=44)\end{array}$ & $\begin{array}{l}\text { Healthy reference Group } \\
(n=44)\end{array}$ & \\
\hline N75 Latency & $95.75(79.5-106.5)$ & 74.9 (71.9-79.2) & $<0.001$ \\
\hline P100 Latency & 126.5 (120.0-139.5) & $100.1(97.6-106.4)$ & $<0.001$ \\
\hline N145 Latency & 159.5 (149.9-175) & $139.3(135-142.7)$ & $<0.001$ \\
\hline N75 Amplitude & $1.0(0.5-1.0)$ & $0.9(0.5-1.4)$ & 0.983 \\
\hline P100 Amplitude & $5.0(3-8)$ & $3.5(2.5-6.9)$ & 0.099 \\
\hline N145 Amplitude & $4.6(2.5-6.6)$ & $4.0(2.8-5.9)$ & 0.900 \\
\hline
\end{tabular}

addition to the primary outcome measures, we also report the latencies and amplitudes of N75 and N145 components.

Baseline PRVEP comparisons between the whole group of patients and the healthy reference group was conducted using Mann-Whitney $U$ test. The outcome measures among the baseline and follow up assessments (FU1 and FU2) were compared within each treatment group (i.e. ONTT+ and ONTT-) separately, with Friedman's ranks test, the nonparametric equivalent of repeated measures one-way analysis of variance. If significant difference was observed in Friedman's ranks test in a group, three post-hoc paired comparisons were done using the Wilcoxon Signed Ranks test to determine the difference in baseline vs. FU1, FU1 vs. FU2 and baseline vs. FU2 assessments. The above post-hoc comparisons were done with a modified Bonferroni correction procedure-the stepwise Hochberg approach-to test statistical significance. The procedure ranks the $p$-values (three $\mathrm{p}$-values in this study) and tests the first (lowest $\mathrm{p}$-value) at $0.05 / 3$. If that is significant, the procedure then tests the next one at $0.05 / 2$; and if that becomes significant, the procedure tests the next one at $0.05 / 1$. If one of the $p$-values is not significant, all those below that on the ranking are not significant [20, 21]. IBM SPSS Statistics for Windows, version 22.0 was used to analyse the data.

\section{Results}

\section{Demographic and clinical characteristics}

Figure 1 shows the numbers of participants initially recruited and retained at each stage of the follow up. There were 44 patients with optic neuritis (24 females; median age: 47.5 (IQR: 37.2-53; range: 18-70) years. All patients had a clinical history of sudden onset visual disturbances, most frequently blurred vision. These patients underwent baseline visual electrophysiological assessment after a median duration of 10 (IQR: 7-20; range 2-21) days following onset of symptoms. Twenty-seven patients complained of unilateral visual impairment while 17 complained of bilateral impairment. The worst clinically affected eye in each patient was taken as the affected eye. The clinical and electrophysiological findings reported and analysed in this paper are of the affected eye of each patient.

Ten patients had normal fundoscopy and 34 showed optic disc edema of the affected eye. Nineteen had undergone magnetic resonance imaging (MRI) and four showed MRI features of multiple sclerosis. Twenty-eight (63.6\%) had ocular pain in the affected eyes at the onset of the clinical symptoms, but none had pain at the time of the visual electrophysiological examination. RAPD was positive in $36(81.8 \%)$ patients. Median N75, P100 and N145 latencies in PRVEP were significantly prolonged in the affected eye of the patient group compared with the healthy reference group; and all 44 patients had

Table 2 Baseline characteristics of ONTT+ vs ONTT- Groups

\begin{tabular}{llll}
\hline Baseline characteristics & ONTT+ Group & ONTT- Group & $P$ value \\
\hline Age (Median (IQR) in years $^{\mathrm{a}}$ & $49(37-53)$ & $47(37-57)$ & 0.673 \\
Proportion (\%) of females $^{\mathrm{b}}$ & $16 / 29(55.2 \%)$ & $8 / 15(53.3 \%)$ & 1.000 \\
Visual acuity (Median (IQR) $^{\mathrm{a}}$ & $0.6(0.5-0.6)$ & $1.0(0.5-1)$ & 0.064 \\
Proportion with eye pain (\%) $^{\mathrm{b}}$ & $20 / 29(69 \%)$ & $8 / 15(53.3 \%)$ & 0.340 \\
Proportion with disc edema (\%) & $22 / 29(75.9 \%)$ & $12 / 15(80 \%)$ & 1.000 \\
Median (IQR) P100 latency (ms) $^{\mathrm{a}}$ & $127(120.5-143.3)$ & $126(118.3-136)$ & 0.683 \\
\hline
\end{tabular}

${ }^{\mathrm{a}}$ Mann-Whitney $\mathrm{U}$ test, ${ }^{\mathrm{b}}$ Fisher's Exact test 
Table 3 Comparison of PRVEPs in affected eyes between baseline, FU1and FU2 assessments in ONTT+ Group

\begin{tabular}{|c|c|c|c|c|c|c|c|}
\hline \multirow{2}{*}{$\begin{array}{l}\text { PRVEP } \\
\text { measure }\end{array}$} & \multicolumn{3}{|l|}{ Median (IQR) } & \multirow{2}{*}{$\begin{array}{l}\text { Overall } p \\
\text { value } \\
\text { (Friedman's } \\
\text { rank test) }\end{array}$} & \multicolumn{3}{|c|}{$P$ value (Wilcoxon's Signed Ranks test) } \\
\hline & Baseline $(n=29)$ & FU1 $(n=29)$ & FU2 $(n=20)$ & & $\begin{array}{l}\text { Baseline vs. FU1 } \\
(n=29)\end{array}$ & $\begin{array}{l}\text { FU1 vs FU2 } \\
(n=20)\end{array}$ & $\begin{array}{l}\text { Baseline vs. FU2 } \\
(n=20)\end{array}$ \\
\hline$\overline{N 75 L}$ & $97.25(79.8-106.4)$ & $78.4(69.6-85.8)$ & $74.1(60.9-86.6)$ & 0.021 & 0.008 & 0.472 & 0.003 \\
\hline P100L & $124.4(121-142.7)$ & $110.9(98.2-123.2)$ & $106.7(94.6-119.8)$ & 0.001 & $<0.001$ & 0.171 & $<0.001$ \\
\hline N145L & $160.1(148.5-178.6)$ & $151.0(138.1-162.9)$ & $151.2(132.7-158.2)$ & 0.016 & 0.012 & 0.732 & 0.008 \\
\hline N75A & $0.7(0.3-1)$ & $1.0(0.25-1)$ & $0.5(0.2-1.0)$ & 0.476 & 0.303 & 0.740 & 0.434 \\
\hline P100A & $4.7(2.8-6.7)$ & $4.6(2.1-7)$ & $3.75(2.3-5.5)$ & 0.534 & 0.746 & 0.177 & 0.456 \\
\hline N145A & $3.5(2.5-6.5)$ & $3.4(1.7-4.4)$ & $4.25(2.9-5.9)$ & 0.157 & 0.50 & 0.204 & 0.948 \\
\hline
\end{tabular}

L Latency, A Amplitude, IQR Inter Quartile Range

P100 latency above $110 \mathrm{~ms}$, our upper limit of normal, signifying demyelinating optic neuritis (Table 1).

There were 29 patients (16 females) in the ONTT+ Group. Their median age was 49 (IQR: 37-53; range: 18-70) years. All 29 attended the FU1 assessment while only $20(69 \%)$ patients were followed up at the FU2. The ONTT- Group consisted of 15 patients (8 females). Their median age was 47 (IQR: 37-57; range: 22-62) years. All 15 patients were assessed at the FU1, but only nine patients $(60 \%)$ attended the FU2. There were no significant differences in the baseline characteristics between the ONTT+ and ONTT-Groups (Table 2).

\section{PRVEP measures in ONTT+ Group vs. ONTT- Group}

In the ONTT+ Group, there was a significant improvement in the median P100 latency values of affected eyes both at 1 month and 3 months after the commencement of treatment. Specifically, the median P100 improved to the normal range as early as 1 month after the commencement of treatment, and the remission lasted until the second follow up assessment at 3 months (Table 3 and Fig. 2).

In the ONTT- Group, there was a significant improvement in median P100 latency values in both the FU1 and FU2 assessments compared to the baseline assessment (Table 4). But the reduction over the 3 months post-baseline was more linear, with partial improvement after 1 month and a further reduction at 3 months (Fig. 2).

There was a significant improvement in LogMAR values of visual acuity at FU1 assessment and further improvement was noted by FU2 in the ONTT+ Group. In

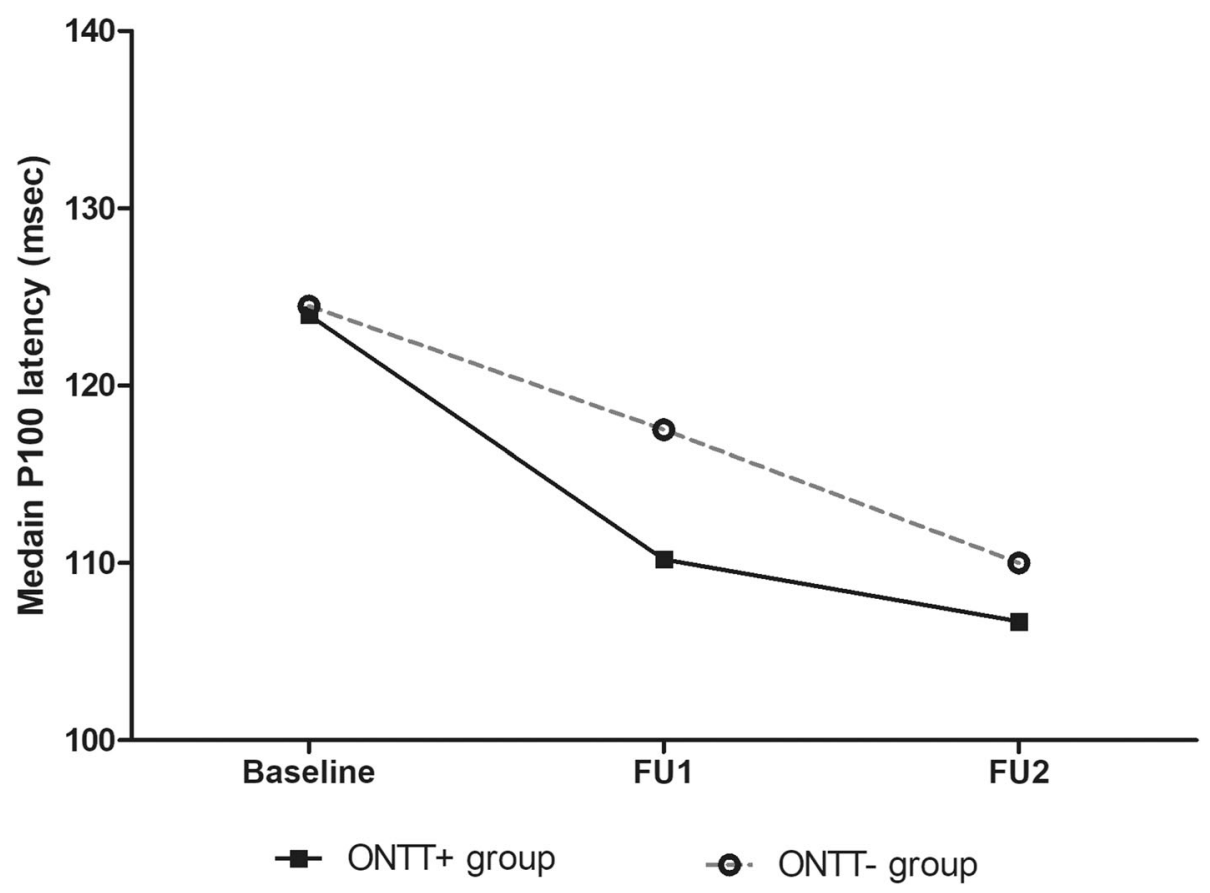

Fig. 2 The median P100 latencies in the ONTT+ and ONTT-Groups at baseline and follow-up assessments 
Table 4 Comparison of PRVEPs in affected eyes between baseline, FU1and FU2 assessments in ONTT- Group

\begin{tabular}{|c|c|c|c|c|c|c|c|}
\hline \multirow{2}{*}{$\begin{array}{l}\text { PRVEP } \\
\text { measure }\end{array}$} & \multicolumn{3}{|l|}{ Median (IQR) } & \multirow{2}{*}{$\begin{array}{l}\text { Overall } p \\
\text { value } \\
\text { (Friedman's } \\
\text { ranks test) }\end{array}$} & \multicolumn{3}{|c|}{ Paired comparisons $p$ value (Wilcoxon's Signed Ranks test) } \\
\hline & $\begin{array}{l}\text { Baseline } \\
(n=15)\end{array}$ & FU1 $(n=15)$ & FU2 $(n=9)$ & & $\begin{array}{l}\text { Baseline vs. FU1 } \\
(n=15)\end{array}$ & $\begin{array}{l}\text { FU1 vs FU2 } \\
(n=9)\end{array}$ & $\begin{array}{l}\text { Baseline vs. FU2 } \\
(n=9)\end{array}$ \\
\hline $\mathrm{N} 75 \mathrm{~L}$ & $95.0(73.4-108.4)$ & $81.5(72.9-86.6)$ & $76.5(61.5-90.9)$ & 0.272 & 0.026 & 0.735 & 0.066 \\
\hline P100L & $124.5(117.6-135.2)$ & $117.5(108.2-122.5)$ & $110.0(103-125)$ & 0.007 & 0.008 & 0.407 & 0.007 \\
\hline N145L & $160.8(154.4-172.1)$ & $156.0(144.9-177.0)$ & $149(142-167.1)$ & 0.293 & 0.055 & 0.155 & 0.038 \\
\hline N75A & $1(0.5-1.15)$ & $1.0(0.5-2)$ & $1.0(0.2-1.0)$ & 0.391 & 0.556 & 0.128 & 0.553 \\
\hline P100A & $6.0(3.2-9.7)$ & $6.5(3-8.5)$ & $6.0(3.7-8.7)$ & 0.539 & 0.706 & 1.000 & 0.678 \\
\hline N145A & $6.5(3.9-9.0)$ & $6.0(3.5-11.9)$ & $6.5(3-8.3)$ & 0.913 & 0.451 & 0.612 & 0.678 \\
\hline
\end{tabular}

L Latency, A Amplitude, IQR Inter Quartile Range

the ONTT- Group, there was a trend of improvement in median LogMAR values of visual acuity over the 3 months duration, but the differences were not statistically significant which might be due to the limited number of subjects (Table 5).

However, in a subsidiary analysis, we did not observe a significant correlation between improvement of P100 latency and LogMAR visual acuity with time in any of the two groups (Table 6). Furthermore, we determined the proportions of patients who had improvement in P100 latency values to normal range which was considered as $<110 \mathrm{~ms}$. In the ONTT+ Group, 11/29 (38\%) and 12/20 (60\%) patients showed improvement in P100 latency values into normal range at FU1 and FU2 respectively. In the ONTT- Group, 6/15 (40\%) and 5/9 (55.5\%) improved to normal range in P100 latency values at FU1 and FU2 respectively. However, a statistical comparison of two groups was not done since the number of each group was low.

\section{Discussion}

In the present study, we observed a significant improvement in median P100 latency values in PRVEP both in the group treated with the ONTT combined regimen and the conservatively managed group. However, the time course of improvement was different in the two groups. In the ONTT combined regimen treated group, the median P100 latency value improved to the normal range 1 month after commencement of treatment. In this group the P100 latencies remained significantly lower than the baseline over next 2 months, but with no further latency reduction over and above that was observed at 1 month. The pattern of P100 latency changes in the conservatively managed group was different: The reduction over the 3 months post-baseline was more linear, with partial improvement after 1 month and a further improvement at 3 months. Although direct intergroup comparisons were not done due to limited sample sizes, the overall improvement tends to be greater in the group treated with ONTT combined regimen (Fig. 2). In combination these observations indicate ONTT regimen, compared to conservative management, achieves early remission in visual conduction abnormalities in optic neuritis.

Our findings are consistent with those of the original ONTT study and other prospective studies that investigated the effect of combined ONTT regimen on visual acuity, colour vision, visual fields and contrast sensitivity in patients with optic neuritis [1,22-24]. The follow up data from the original ONTT study shows that the combined ONTT regimen elicits a significant improvement in visual acuity, contrast sensitivity and visual fields sooner than the placebo group and the group treated with oral prednisolone $[1,25]$. In that study, combined ONTT regimen elicited a significant improvement in visual acuity, contrast sensitivity and visual fields by 1 month and then the rate of improvement gradually declined. By around 3 months, about $50-70 \%$ of the patients had normal visual outcome measures. Similar to the present findings, the groups that received placebo and oral prednisolone showed a more linear recovery. Our findings provide additional electrophysiological

Table 5 Comparison of visual acuity across baseline, FU1 and FU2 assessments in ONTT+ and ONTT- Groups

\begin{tabular}{|c|c|c|c|c|c|c|c|}
\hline \multirow[t]{2}{*}{$\begin{array}{l}\text { Study } \\
\text { Group }\end{array}$} & \multicolumn{3}{|c|}{$\begin{array}{l}\text { Visual acuity } \\
\text { LogMAR median (IQR) }\end{array}$} & \multirow{2}{*}{$\begin{array}{l}\text { Overall } p \\
\text { value } \\
\text { (Friedman's } \\
\text { rank test) }\end{array}$} & \multicolumn{3}{|c|}{$P$ value (Wilcoxon's Signed Ranks test) } \\
\hline & Baseline & FU1 & FU2 & & Baseline vs. FU1 & FU1 vs FU2 & Baseline vs. FU2 \\
\hline ONTT+ & $+0.6(0.5-0.6)$ & $+0.3(0.0-0.6)$ & $+0.2(0.0-0.45)$ & $<0.001$ & $0.001(n=29)$ & $0.076(n=20)$ & $0.001(n=20)$ \\
\hline ONTT- & $+1.0(0.5-1.5)$ & $+0.8(0.1-1.65)$ & $+0.2(0.05-1.4)$ & 0.013 & $0.023(n=15)$ & $0.068(n=9)$ & $0.027(n=9)$ \\
\hline
\end{tabular}


Table 6 Correlation between improvement in VEP P100 latency and LogMAR visual acuity at follow up assessments

\begin{tabular}{lcl}
\hline Comparison & \multicolumn{2}{c}{ Spearman correlation coefficient ( $\boldsymbol{p}$ value) } \\
\cline { 2 - 3 } & ONTT+ Group & ONTT- Group \\
\hline Baseline to follow-up 1 & $0.11(0.56)$ & $0.46(0.09)$ \\
Baseline to follow up 2 & $-0.03(0.91)$ & $0.29(0.44)$ \\
\hline
\end{tabular}

evidence supporting more rapid improvement of visual conduction in optic neuritis in the group treated with combined corticosteroids.

Although the effect of combined ONTT regimen on PRVEP has not been assessed before, a few follow up studies have assessed the effectiveness of either oral or intravenous corticosteroids on PRVEP in patients with optic neuritis [5-10] (Table 7). Of those, one randomized controlled trial has shown that oral corticosteroids improve P100 PRVEP latencies by 1 month [5], whereas another randomized controlled trial has shown that oral corticosteroids can be used as an alternative to IV

Table 7 Summary of studies that assessed PRVEP changes following corticosteroid treatment in optic neuritis

\begin{tabular}{|c|c|c|c|c|c|c|c|}
\hline $\begin{array}{l}\text { Study \& } \\
\text { Country }\end{array}$ & $\begin{array}{l}\text { Type of } \\
\text { study }\end{array}$ & $\begin{array}{l}\text { Number of } \\
\text { participants }\end{array}$ & $\begin{array}{l}\text { Duration } \\
\text { of } \\
\text { symptoms }\end{array}$ & $\begin{array}{l}\text { Route of administration, } \\
\text { dose and duration }\end{array}$ & $\begin{array}{l}\text { Follow } \\
\text { up }\end{array}$ & $\begin{array}{l}\text { Improvement in } \\
\text { visual acuity }\end{array}$ & $\begin{array}{l}\text { Improvement in PRVEP P100 } \\
\text { latency }\end{array}$ \\
\hline $\begin{array}{l}\text { Smith } \\
\text { et al., } \\
1986 \text { [8] } \\
\text { Denmark }\end{array}$ & Case series & 10 & $\begin{array}{l}\text { Within } 24 \\
\mathrm{~h} \text { of onset }\end{array}$ & $\begin{array}{l}\text { IV Methylprednisolone } 1 \mathrm{~g} \\
\text { daily for } 3 \text { days }\end{array}$ & $\begin{array}{l}1 \text { week } \\
\text { and } 1 \\
\text { month }\end{array}$ & Not quantified. & $\begin{array}{l}\text { No significant improvement; } \\
\text { mean (SE) } \\
\text { Before: } 132(3.3) \\
1 \text { week: } 127(5.8) \\
1 \text { month:134 (3.2) }\end{array}$ \\
\hline $\begin{array}{l}\text { Trauzettel- } \\
\text { Klosinski } \\
\text { et al., } \\
1995 \text { [5] } \\
\text { Germany }\end{array}$ & $\begin{array}{l}\text { Randomized } \\
\text { controlled } \\
\text { trial }\end{array}$ & $\begin{array}{l}\text { Test group: } \\
15 \\
\text { Placebo: } 33\end{array}$ & $\begin{array}{l}3 \text { weeks } \\
\text { since } \\
\text { onset }\end{array}$ & $\begin{array}{l}\text { Test group: oral } \\
\text { Methylprednisolone } 100 \text { mg } \\
\text { daily for } 3 \text { days followed by } \\
\text { tapered dose reduction in } \\
\text { every } 3 \text { days up to } 24 \text { days. } \\
\text { Placebo: oral thiamine } 100 \\
\text { mg daily for } 24 \text { days }\end{array}$ & $\begin{array}{l}1 \text { week, } \\
1,3 \text { and } \\
12 \\
\text { months } \\
\text { after } \\
\text { onset }\end{array}$ & $\begin{array}{l}1 \text { week: Improved in } \\
\text { both groups. } \\
\text { Slightly in favor of } \\
\text { oral group without } \\
\text { statistical } \\
\text { significance } \\
3 \text { and } 12 \text { months: } \\
\text { no significant } \\
\text { difference in } \\
\text { improvement in } \\
\text { both groups } \\
12 \text { months: } \\
\text { normalized in most } \\
\text { patients in both } \\
\text { groups }\end{array}$ & $\begin{array}{l}\text { Between group analysis: } \\
1 \text { month: Significant } \\
\text { improvement in the test } \\
\text { group. } \\
3 \text { and } 12 \text { months: no } \\
\text { significant difference in } \\
\text { improvement between two } \\
\text { groups. } \\
\text { within-subject analysis } \\
\text { Test group } \\
1 \text { month: borderline significant } \\
\text { improvement } \\
3 \text { and } 12 \text { months: no } \\
\text { significant difference in } \\
\text { improvement } \\
\text { Placebo group } \\
\text { no significant difference of } \\
\text { improvement over the time }\end{array}$ \\
\hline $\begin{array}{l}\text { Kapoor } \\
\text { et al., } \\
1998[6] \\
\text { United } \\
\text { Kingdom }\end{array}$ & $\begin{array}{l}\text { Randomized } \\
\text { controlled } \\
\text { trial }\end{array}$ & $\begin{array}{l}\text { Test group: } \\
33 \\
\text { Placebo: } 31\end{array}$ & $\begin{array}{l}\text { Within } 30 \\
\text { days of } \\
\text { onset }\end{array}$ & $\begin{array}{l}\text { IV Methylprednisolone } 1 \mathrm{~g} \\
\text { daily for } 3 \text { days } \\
\text { Placebo: Normal saline for } 3 \\
\text { days }\end{array}$ & $\begin{array}{l}2 \text { weeks, } \\
3 \\
\text { months } \\
\text { and } 6 \\
\text { months }\end{array}$ & Not quantified & $\begin{array}{l}\text { IV corticosteroids have no } \\
\text { effect on VEP latency } \\
\text { improvement at } 2 \text { weeks, } 3 \text { and } \\
6 \text { months }\end{array}$ \\
\hline $\begin{array}{l}\text { Sethi } \\
\text { et al., } \\
2006 \text { [9] } \\
\text { India }\end{array}$ & Case series & 33 eyes & $\begin{array}{l}\text { Within 2- } \\
15 \text { days }\end{array}$ & $\begin{array}{l}\text { IV dexamethasone } 100 \text { mg } \\
\text { for } 3 \text { days }\end{array}$ & $\begin{array}{l}3 \\
\text { months }\end{array}$ & $\begin{array}{l}3 \text { months: } \\
V A \geq 20 / 20 \\
\text { achieved in } 16 \\
(57.14 \%) \text { eyes }\end{array}$ & $\begin{array}{l}\text { Statistically significant } \\
\text { improvement was seen at } 3 \\
\text { months with IV corticosteroids }\end{array}$ \\
\hline $\begin{array}{l}\text { Morrow } \\
\text { et al., } \\
2018[7] \\
\text { Canada }\end{array}$ & $\begin{array}{l}\text { Randomized } \\
\text { controlled } \\
\text { trial }\end{array}$ & $\begin{array}{l}\text { IV group: } 23 \\
\text { Oral group: } \\
22\end{array}$ & $\begin{array}{l}\text { Within } 14 \\
\text { days of } \\
\text { onset }\end{array}$ & $\begin{array}{l}\text { IV Methylprednisolone } 1000 \\
\text { mg daily for } 3 \text { days } \\
\text { Oral prednisolone } 1250 \mathrm{mg} \\
\text { daily for } 3 \text { days }\end{array}$ & $\begin{array}{l}1 \text { and } 6 \\
\text { months }\end{array}$ & $\begin{array}{l}\text { IV Group: median } \\
\text { Baseline: } 20 / 100 \\
1 \text { month:20/20 } \\
6 \text { months:20/20 } \\
\text { Oral Group: median } \\
\text { Baseline: } 20 / 160 \\
1 \text { month:20/36 } \\
6 \text { months:20/32 } \\
\text { recovery not } \\
\text { significantly } \\
\text { different between } \\
\text { the groups }\end{array}$ & $\begin{array}{l}\text { IV Group: Mean (SD) } \\
\text { Baseline: } 181.9 \text { (53.6) } \\
1 \text { month: } 140.1(28.5) \\
6 \text { months: } 119.0 \text { (16.5) } \\
\text { Oral Group: Mean (SD) } \\
\text { Baseline: } 200.5(67.2) \\
1 \text { month: } 145.4(41.5) 6 \text { months: } \\
133.8 \text { (31.5) } \\
\text { no significant difference in } \\
\text { improvement between the } \\
\text { groups. Thus, oral } \\
\text { corticosteroids can be used as } \\
\text { an alternative to IV } \\
\text { corticosteroids to treat acute } \\
\text { optic neuritis }\end{array}$ \\
\hline
\end{tabular}


corticosteroids to treat acute optic neuritis [7]. Another randomized controlled trial has shown that no PRVEP improvement occurs with IV corticosteroids even by 3 months [6]. Similarly, a case series suggests that IV corticosteroids improve P100 PRVEP at 3 months [9], while another series has shown that IV corticosteroids are not associated with recovery of PRVEP by 1 month [8].

PRVEP latency prolongation is a measure of the degree of demyelination of the visual conduction pathways: recovery of latencies therefore signifies remyelination. Improvement of the PRVEP latencies that we observed in patients with optic neuritis is due to the remyelination process, and restoration of ionic conductance along the optic nerve pathways [26, 27]. Furthermore, early treatment with steroids in optic neuritis was found to minimize axonal loss as indexed by retinal nerve fiber layer thickness assessments with optical coherence tomography [28]. Fluorescence microscopy on experimental animals has shown that corticosteroids can suppress optic neuritis and prevent retinal ganglion cell loss, if corticosteroid treatment is initiated in the early phase of the disease [29].

Our study, however, is limited in assessing the retinal morphology as we could not measure the retinal layer thicknesses with optical coherence tomography in the present study. Another limitation of our study is that it was underpowered to compare the proportions of patients who had complete recovery of VEPs between the two treatment arms, owing to small number of subjects.

\section{Conclusions}

To the best of our knowledge, present study is the first to evaluate the efficacy of ONTT combined regimen on the recovery of optic neuritis compared with conservative management as assessed by PRVEP. We conclude that management of patients either conservatively or with combined ONTT regimen improves visual conduction significantly at 3 months, though the ONTT combined regimen accelerated the recovery, showing a clinically significant improvement of visual conduction as early as 1 month.

\section{Abbreviations \\ EMG: Electromyography; IQR: Inter quartile range; ISCEV: International society for clinical electrophysiology of vision; LogMAR: Logarithm of the minimal angle of resolution; MRI: Magnetic resonance imaging; PERG: Pattern electroretinography; PRVEP: Pattern reversal visual evoked potentials \\ Acknowledgments \\ Authors wish to thank all the participants in the study and consultant ophthalmologists who referred patients for the study.}

\section{Authors' contributions}

PD designed the study, collected and analyzed data and drafted the manuscript. TLD designed the study, analyzed data, reviewed and edited the manuscript, MP designed the study, analyzed data, reviewed and edited the manuscript, SS designed the study, collected clinical data, analyzed data, reviewed and edited the manuscript, MS designed the study, analyzed data, reviewed and edited the manuscript. VSW designed the study, analyzed the data, reviewed and edited the manuscript. All authors read and approved the final manuscript.

\section{Funding}

This research was funded by University of Peradeniya research grant (URG) 2016/44/M) only to purchase the Nicolet Viking Quest EMG/NCV/EP machine.

Availability of data and materials

The data sets used and/or analysed during the current study are available from the corresponding author on request.

\section{Declarations}

Ethics approval and consent to participate

Ethical clearance (2016/EC/50) for the study was obtained from the Ethical Review Committee, Faculty of Medicine, University of Peradeniya, Sri Lanka. The study design and protocols complied with the code of ethics of the World Medical Association Declaration of Helsinki [11]. The procedures were explained and informed written consent obtained from all participants.

Consent for publication

Not applicable.

Competing interests

The authors declare that they have no competing interests.

\section{Author details}

${ }^{1}$ Department of Physiology, Faculty of Medicine, University of Peradeniya, Peradeniya 20400, Sri Lanka. ${ }^{2}$ Teaching Hospital, Peradeniya 20400, Sri Lanka. ${ }^{3}$ School of Psychology, The University of Newcastle, Callaghan, NSW 2308, Australia. ${ }^{4}$ Department of Medicine, Faculty of Medicine, University of Peradeniya, Peradeniya 20400, Sri Lanka. ${ }^{5}$ Eye Unit, National Hospital, Kandy 20000, Sri Lanka.

Received: 21 February 2021 Accepted: 27 August 2021

Published online: 06 September 2021

References

1. Beck RW, Cleary PA, Anderson MM, Keltner JL, Shults WT, Kaufman DI, et al. A randomized, controlled trial of corticosteroids in the treatment of acute optic neuritis. N Engl J Med. 1992;326(9):581-8. https://doi.org/10.1056/ nejm199202273260901.

2. Brigell M, Kaufman DI, Bobak P, Beydoun A. The pattern visual evoked potential. Doc Ophthalmol. 1994;86(1):65-79. https://doi.org/10.1007/BF01224629.

3. Brigell M. Pattern visual evoked potentials in treatment trials for optic neuropathy. Arch Ophthalmol. 1994;112(3):299-300. https://doi.org/10.1 001/archopht.1994.01090150029006.

4. Al-Eajailat SM, Al-Madani Senior MV. The role of magnetic resonance imaging and visual evoked potential in management of optic neuritis. Pan Afr Med J. 2014;17:54. https://doi.org/10.11604/pamj.2014.17.54.2462.

5. Trauzettel-Klosinski S, Diener HC, Dietz K, Zrenner E. The effect of oral prednisolone on visual evoked potential latencies in acute optic neuritis monitored in a prospective, randomized, controlled study. Doc Ophthalmol. 1995;91(2):165-79. https://doi.org/10.1007/bf01203696.

6. Kapoor R, Miller DH, Jones SJ, Plant GT, Brusa A, Gass A, et al. Effects of intravenous methylprednisolone on outcome in MRI-based prognostic subgroups in acute optic neuritis. Neurology. 1998;50(1):230-7. https://doi. org/10.1212/WNL.50.1.230.

7. Morrow SA, Fraser JA, Day C, Bowman D, Rosehart H, Kremenchutzky M, et al. Effect of treating acute optic neuritis with bioequivalent oral vs intravenous corticosteroids: a randomized clinical trial. JAMA Neurol. 2018; 75(6):690-6. https://doi.org/10.1001/jamaneurol.2018.0024.

8. Smith T, Zeeberg I, Sjö O. Evoked potentials in multiple sclerosis before and after high-dose methylprednisolone infusion. Eur J Neurol. 1986;25(1):67-73. https://doi.org/10.1159/000115989.

9. Sethi H, Menon V, Sharma P, Khokhar S, Tandon R. Visual outcome after intravenous dexamethasone therapy for idiopathic optic neuritis in an Indian population: a clinical case series. Indian J Ophthalmol. 2006:54(3): 177-83. https://doi.org/10.4103/0301-4738.27069. 
10. Liu Q, Zhang M, Ai F, Jiang R, Hu T. Treatment of acute optic neuritis with high dose of prednisone. Zhongguo Yi Xue Ke Xue Yuan Xue Bao. 1998;20(3):230-5.

11. Association WM. World Medical Association Declaration of Helsinki: ethical principles for medical research involving human subjects. JAMA. 2013; 310(20):2191-4. https://doi.org/10.1001/jama.2013.281053.

12. Holder GE. Electrophysiological assessment of optic nerve disease. Eye. 2004;18(11):1133-43. https://doi.org/10.1038/sj.eye.6701573.

13. Dahanayake P, Dassanayake TL, Pathirage M, Colombage A, Gawarammana IB, Senanayake S, et al. Dysfunction in macula, retinal pigment epithelium and post retinal pathway in acute organophosphorus poisoning. Clin Toxicol. 2020;59(2):1-7. https://doi.org/10.1080/15563650.2020.1771359.

14. Odom JV, Bach M, Brigell M, Holder GE, McCulloch DL, Mizota A, et al. ISCEV standard for clinical visual evoked potentials: (2016 update). Doc Ophthalmol. 2016;133(1):1-9. https://doi.org/10.1007/s10633-016-9553-y.

15. Beck RW, Cleary PA. Optic neuritis treatment trial. One-year follow-up results. Arch Ophthalmol. 1993;111(6):773-5. https://doi.org/10.1001/a rchopht.1993.01090060061023.

16. Menon V, Saxena R, Misra R, Phuljhele S. Management of optic neuritis. Indian J Ophthalmol. 2011;59(2):117-22. https://doi.org/10.4103/0301-4738.77020.

17. Kaufman DI. Acute optic neuritis. Curr Treat Options Neurol. 1999;1 (1):44-8 https://doi.org/10.1007/s11940-999-0031-7.

18. Pula JH, Macdonald CJ. Current options for the treatment of optic neuritis. Clin Ophthalmol. 2012;6:1211-23. https://doi.org/10.2147/opth.s28112.

19. Naismith RT, Tutlam NT, Xu J, Shepherd JB, Klawiter EC, Song SK, et al. Optical coherence tomography is less sensitive than visual evoked potentials in optic neuritis. Neurology. 2009;73(1):46-52. https://doi.org/1 0.1212NNL.0b013e3181aaea32.

20. Kim H-Y. Statistical notes for clinical researchers: nonparametric statistical methods: nonparametric methods for comparing three or more groups and repeated measures. Restor Dent Endod. 2014;39(4):329-32. https://doi.org/1 0.5395/rde.2014.39.4.329

21. Dassanayake TL, Jones AL, Michie PT, Carter GL, McElduff P, Stokes BJ, et al. Risk of road traffic accidents in patients discharged following treatment for psychotropic drug overdose: a self-controlled case series study in Australia. CNS Drugs. 2012;26(3):269-76. https://doi.org/10.2165/11599790-000000000-00000.

22. Wakakura M, Mashimo K, Oono S, Matsui Y, Tabuchi A, Kani K, et al. Multicenter clinical trial for evaluating methylprednisolone pulse treatment of idiopathic optic neuritis in Japan. Optic Neuritis Treatment Trial Multicenter Cooperative Research Group (ONMRG). Jpn I Ophthalmol. 1999; 43(2):133-8. https://doi.org/10.1016/s0021-5155(98)00071-9.

23. Toczołowski J, Lewandowska-Furmanik M, Stelmasiak Z, Woźniak D, Chmiel M. Treatment of acute optic neuritis with large doses of corticosteroids. Klin Ocz. 1995;97(5):122-5.

24. Menon V, Mehrotra A, Saxena R, Jaffery NF. Comparative evaluation of megadose methylprednisolone with dexamethasone for treatment of primary typical optic neuritis. Indian J Ophthalmol. 2007:55(5):355-9. https:// doi.org/10.4103/0301-4738.33821.

25. Bennett JL, Nickerson M, Costello F, Sergott RC, Calkwood JC, Galetta SL, et al. Re-evaluating the treatment of acute optic neuritis. J Neurol Neurosurg Psychiatry. 2015;86(7):799-808. https://doi.org/10.1136/jnnp-2014-308185.

26. Yang EB, Hood DC, Rodarte C, Zhang X, Odel JG, Behrens MM. Improvement in conduction velocity after optic neuritis measured with the multifocal VEP. Investig Ophthalmol Vis Sci. 2007;48(2):692-8. https://doi. org/10.1167/iovs.06-0475.

27. Miller DH, Thompson AJ, Morrissey SP, MacManus DG, Moore SG, Kendall BE, et al. High dose steroids in acute relapses of multiple sclerosis: MRI evidence for a possible mechanism of therapeutic effect. J Neurol Neurosurg Psychiatry. 1992;55(6):450-3. https://doi.org/10.1136/jnnp.55.6.450

28. Nakamura M, Nakazawa T, Doi H, Hariya T, Omodaka K, Misu T, et al. Early highdose intravenous methylprednisolone is effective in preserving retinal nerve fiber layer thickness in patients with neuromyelitis optica. Graefes Arch Clin Exp Ophthalmol. 2010;248(12):1777-85. https://doi.org/10.1007/s00417-010-1344-7.

29. Dutt M, Tabuena P, Ventura E, Rostami A, Shindler KS. Timing of corticosteroid therapy is critical to prevent retinal ganglion cell loss in experimental optic neuritis. Invest Ophthalmol Vis Sci. 2010;51(3):1439-45. https://doi.org/10.1167/iovs.09-4009.

\section{Publisher's Note}

Springer Nature remains neutral with regard to jurisdictional claims in published maps and institutional affiliations.

Ready to submit your research? Choose BMC and benefit from:

- fast, convenient online submission

- thorough peer review by experienced researchers in your field

- rapid publication on acceptance

- support for research data, including large and complex data types

- gold Open Access which fosters wider collaboration and increased citations

- maximum visibility for your research: over $100 \mathrm{M}$ website views per year

At $\mathrm{BMC}$, research is always in progress.

Learn more biomedcentral.com/submissions 